LBL --29282

DE91 013850

\title{
Basic Research for Assessment of Geologic Nuclear Waste Repositories: What Solubility and Speciation Studies of Transuranium Elements Can Tell Us
}

\author{
Heino Nitsche \\ Earth Sciences Division \\ Lawrence Berkeley Laboratory \\ University of California \\ Berkeley, California 94720
}

December 1990

This work was supported by the Yucca Mountain Sile Characterization Project Office as part of the U.S. Civilian Radioactive Waste Management Project through the Los Alamos National Laboratory. The Yurca Mountain Project is managed by the U.S. Department of Energy. Yucca Mountain Project. This work was performed at the Lawrence Berkeley Laboratory, which is operated by the University of California for the U.S. Department of Energy under Contract DE-AC03-76SF00098. 


\title{
BASIC RESEARCH FOR ASSESSMENT OF GEOLOGIC NUCLEAR WASTE REPOSITORIES: WHAT SOLUBILITY AND SPECIATION STUDIES OF TRANSURANIUM ELEMENTS CAIN TELL US
}

\author{
HENNO NITSCHE \\ Lawrence Berkeley Laboratory, Darth Sciences Division, 1 Cyclotron Road, Mail Stop \\ 70A-1150, Berkeley, California 94720
}

\begin{abstract}
Solubility and speciation data are important in understanding aqueous radionuclide transport through the geosphere. They define the source term for transport retardation processes such as sorption and colloid formation. Solubility and speciation data are useful in verifying the validity of geochemical codes that are part of predictive transport models. Results from solubility and speciation experiments of ${ }^{\mathrm{M}} \mathrm{NpO}_{2}^{+},{ }^{2 n} \mathrm{Pu}^{4 *}$, and ${ }^{2+1} \mathrm{Am}^{3 *} / \mathrm{Nd}^{3 *}$ in J-13 groundwater (from the Yucca Mountain region, Nevada, which is being investigated as a candidate high-level nuclear waste disposal site) at three different temperatures $\left(25^{\circ}, 60^{\circ}\right.$, and $90^{\circ} \mathrm{C}$ ) and $\mathrm{ph}$ values $(6,7$, and 8.5$)$ are presented and compared with published modeling calculations. The comparison results indicate that there is a great need for experimental data on the solubility and speciation of transuranium elements under a wide range of conditions, for example, $\mathrm{pH}$, Eh, temperature, and composition of groundwaters. Additionally, the influence of alpha radiation and the radiolysis of the secondary transuranium solids on solubility and speciation should be studied. Solubility studies and model calculations should be extended to other important long-lived nuclear waste radionuclides such as nickel, zirconium, cadmium, radium, and thorium.
\end{abstract}

INTERCONNECTIONS OF SOLUBILITY AND SPECIATION STUDIES WTTH OTHER TRANSPORT-CONTROLLING PROCESSES

Gaseous and aqueous transport are two principal mechanisms of radionuclide transport from a potential nuclear waste repository to the environment. Aqueous radionuclide migration through the geosphere is controlled by several chemical and physicochemical phenomena, including the dissolution rate of the waste package, formation of secondary solids, radionuclide complexation in the solution phase, and sorption processes on the geomedia. These processes are interconnected and depend strongly on each other.

Solubility may limit the concentration of radionuclides in the aqueous phase. It is controlled by the formation of solubility-controlling secondary solids that are in equilibrium with soluble species. The soluble species in turn can form solution complexes by reacting with ligands that are present in the groundwater. Complex formation is dependent on the oxidation state and charge of the radionuclide in the solution phase, as well as the nature and the amount of potentially complexing ligands present in the groundwater. The electrical charges of the solution complexes can vary widely. Detailed knowledge of the species and associated charges are very important for understanding their sorption on the g*omedia. Differently charged species adsorb differently. For example, many mineral surfaces act as weak acids; they are protonated at lower $\mathrm{pH}$ values, and they deprotonate at environmental $\mathrm{pH}$ levels, at pH 6 and above, to form negatively charged surfaces. Such surfaces readily adsorb cations like Am" [1]. They do not adsorb uncomplexed anions such as $\mathrm{TcO}_{4}-[2]$. However, when anionic potentially complexing ligands are present in the solution, the negatively charged surfaces compete with the ligands for the metal ion complexation. These phenomena are described by surface complexation theories, which are based on double- or triple-layer models [3-5]. Understanding of sorption processes is also very beneficial in understanding colloidal transport. Colloid transport can be seen as a special form of aqueous transport in which colloidal polynuclear radionuclides and radionuclides that attach themselves to suspended solid material can be transported. 


\section{APPLICATIONS OF SOLUBILITY AND SPECIATION DATA}

Solubility studies of radionuclides yield good estimates of uppermost radionuclide concentrations in groundwaters from the region of potential waste repositories. Such measurements will provide upper concentration limits because the secondary steady-state solids formed can still change from a higher to a lower free energy, which would result in lower solution concentrations. These changes may be very slow and may require very long or even infinite experimental times, which are not practical.

\section{Model Verification. Data Base Validation, and Risk Assessment}

Data derived from solubility studies are important for validating geochemical codes that are part of predictive radionuclide transport models. Such codes should be capable of predicting the results of solubility experiments. Furthermore, agrcement between geochemical calculations and experimental results can validate the thermodynamic data base used with the modeling calculation.

To predict behavior at higher temperatures, data bases used for modeling calculations must contain data on thermodynamic functions at elevated temperatures. To date, many of these data are unavailable and are therefore estimated by extrapolation from lower temperature data. Agreement between modeling calculations and experimental results would also validate such estimates, whereas significant discrepancies would identify the need for data base improvement. Improvements can be made by filling the gaps with generic experimental data.

In addition, experimental solubility data also provide the source terms or the starting concentrations for experimental sorption studies. To be valid, sorption studies should be conducted at or below the solubility limit because only soluble species can be transported and participate in the sorption process.

\section{SOLUBLIT MEASUREMENTS FOR THE YUCCA MOUNTAIN PROJECT}

\section{Concept}

The concept of solubility and speciation measurements has been discussed and illustrited [6]. In quintessence, meaningful thermodynamically defined solubility studies should satisfy four criteria: (1) equilibrium conditions, (2) accurate solution concentrations, (3) a well-defined solid phase, and (4) knowledge of the speciation/oxidation state of the soluble species at equilibrium. This study was conducted according to these criteria.

\section{Experimental Approach}

The solubilities of ${ }^{27} \mathrm{NpO}_{2}^{*},{ }^{29} \mathrm{Pu}^{4 *}$, and ${ }^{21} \mathrm{Am}^{3 *} / \mathrm{Nd}^{3 *}$ were determined in $\mathrm{J}-13$ groundwater from the Yucca Mountain region in Nevada. To bracket a variety of possible pH and temperature conditions, solubility and speciation data were obtained for each radionuclide solution at three different $\mathrm{pH}$ yalues ( $\mathrm{pH} 6,7$, and 8.5) and at three temperatures $\left(25^{\circ}, 60^{\circ}\right.$, and $\left.90^{\circ} \mathrm{C}\right)$. Further experimental details are described elsewhere $[6,7]$.

\section{Modeling Calculations}

Recently, Wilson and Bruton [8] published results of modeling calculations for actinides in $\mathrm{J}-13$ water at $\mathrm{pH} 7$ and at $25^{\circ} \mathrm{C}$ and $90^{\circ} \mathrm{C}$. The data were derived by using the geochemical modeling code EQ 3/6 (version 3245) [9] and the supporting thermodynamic data base (version $3270 \mathrm{R} 13$ ). The simulation process yielded the precipitating solids and the corresponding actinide concentration in solution. 
Speciation calculations for neprunium, plutonium, and americium in $\mathrm{J}-13$ water (pH 7 is the natural $\mathrm{pH}$ of $\mathrm{J}-13$ water) at $25^{\circ} \mathrm{C}$ were performed by Miller and Silva [10], who also used the EQ 3/6 code (version 3245) and a modified thermodynamic data base. Modifications of the data base were necessary because many data are unavailable in the original data base for possible solution species in J-13 groundwater. Tables I to IVb show the stability constants used in the calculations for the reactions of neptunium, plutonium, and americium with ligands present in J-13 groundwater. Italic numbers indicate that no data were available and that estimates were used instead; the estimates were derived from other actinide systems of the same oxidation state.

Table I. Complex Stability Constants for Selected Trivalent Actinides

\begin{tabular}{|c|c|c|c|c|c|c|c|c|c|c|}
\hline \multirow[b]{2}{*}{ somoin } & \multirow{2}{*}{ • } & \multicolumn{9}{|c|}{ Lifind } \\
\hline & & oir & $F$ & $c^{m}$ & $\mathrm{Na}_{4}^{\prime \prime}$ & $\mathrm{H}_{2} \mathrm{FO}_{4}^{-1}$ & $\mathrm{co}^{\mathrm{X}}$ & $\operatorname{sos}^{2 m}$ & HPQ & $\mathrm{PO}^{3-}$ \\
\hline $\mathrm{Ams}^{3+}$ & 1 & 7,97 & 3.73 & 1.13 & 1.4 & 2.58 & 7.90 & $3.93-$ & & \\
\hline $\mathrm{sip}^{30}$ & 1 & 7.19 & 3,73 & 1.13 & 1.41 & 239 & 700 & 3.93 & & \\
\hline$n^{3+}$ & 1 & 8.51 & 3.73 & 0.9 & 1.09 & 264 & 700 & 3.20 & & \\
\hline $\mathrm{Am}^{3+}$ & 2 & sy.se & 283 & os & 1.92 & 3.98 & 12.20 & 5.45 & & \\
\hline $\mathrm{Ne}^{3+}$ & 2 & If.s: & 303 & osz & 1.92 & 3.73 & 12.20 & 5.45 & & \\
\hline $\mathrm{pu}^{3+}$ & 2 & state & $2 \pi$ & 0.82 & 222 & 4.08 & 12.20 & 6.32 & & \\
\hline $\min ^{3+}$ & 3 & 18.08 & 11.04 & & 252 & 4.99 & 1270 & & & \\
\hline $\mathrm{Sp}^{3+}$ & 3 & 18.06 & $110 a$ & & 2.52 & 5.64 & 12.70 & & & \\
\hline $\mathrm{pu}^{34}$ & 3 & 18.08 & 11.08 & & 2.52 & 5.04 & 12.70 & & & \\
\hline $\mathrm{Am}^{3+}$ & 4 & & & & . & 5.55 & & & & \\
\hline $\mathrm{Sip}^{3+}$ & 4 & & & & & 5,55 & & & & \\
\hline $\mathrm{m}^{3+}$ & 4 & & & & & 5.65 & & & & \\
\hline
\end{tabular}

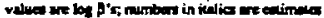

Table II. Complex Stability Constants for Selected Teuavalent Actinides

\begin{tabular}{|c|c|c|c|c|c|c|c|c|c|c|}
\hline \multirow[b]{2}{*}{ spesies } & \multirow{2}{*}{$\begin{array}{c}\bullet \\
\text { Lienda }\end{array}$} & \multicolumn{9}{|c|}{ Liund } \\
\hline & & 아 & $F$ & $\mathrm{Cr}^{\prime}$ & $\mathrm{NO}_{1}^{-}$ & $\mathrm{H}_{2} \mathrm{PO}_{2}$ & $\mathrm{CO}_{1}^{2-}$ & $\mathrm{sO}_{1}^{2-2}$ & $\mathrm{HPO}_{1}^{2}$ & $\mathrm{PO}^{3-}$ \\
\hline$A \pi^{4+}$ & 1 & 13.45 & 9.24 & 1.71 & 1.13 & 4.92 & 12,30 & 8.40 & 16.00 & \\
\hline$x_{p}^{4+4}$ & 1 & 1295 & 161 & 1.19 & 1.15 & .92 & 12.30 & 6.51 & 16.00 & \\
\hline $\mathrm{Pa}^{46}$ & 1 & 13.67 & 3.45 & 1.16 & 1.7 & 4.92 & 12.30 & 0.76 & 16.00 & \\
\hline $\mathrm{Mm}^{4+}$ & 2 & $2 \div 20$ & 16.03 & 1.68 & 2.26 & 810 & 23.35 & 10.36 & 28.53 & \\
\hline$s_{p}^{4+}$ & 2 & 2130 & 15.70 & 1.64 & 231 & 8.50 & 23.35 & 9.79 & 28.13 & \\
\hline $\mathrm{m}^{4+}$ & 2 & 25.20 & is.t2 & 2.16 & 3.36 & 8.30 & 23.35 & 10,36 & 28.13 & \\
\hline $\mathrm{Am}^{1+}$ & 3 & ues & 21.06 & 2.41 & 251 & & 10,00 & .30 & 3790 & \\
\hline $\mathrm{Sp}^{4+}$ & 3 & 305 & 2136 & 241 & 3.51 & & 90.00 & 8.30 & 37.90 & \\
\hline$p^{4 *}$ & 3 & 39.85 & 20.70 & 0.09 & 3.15 & & 30.00 & 8.30 & 37.90 & \\
\hline $\mathrm{Am}^{4+}$ & 4 & 31.45 & 25.25 & & 2.75 & 13,45 & 31000 & & 45.65 & \\
\hline$s_{p} u^{4+}$ & 4 & 51.45 & 25.25 & & 275 & 1345 & 31.00 & & 45.65 & \\
\hline$p^{4+4}$ & 4 & 49.20 & 25.00 & & 2.75 & 13.15 & 33.00 & & 45.65 & \\
\hline $\mathrm{Am}^{4+}$ & 5 & 5930 & $26 \mathrm{AS}$ & & & & 34.00 & & 400 & \\
\hline $\mathrm{Ne}^{4+}$ & 5 & 53.00 & $26 t 3$ & & & & 34.00 & & 480 & \\
\hline $\mathrm{B}^{4+}$ & 5 & 53.20 & 2683 & & & & 3400 & & 48.60 & \\
\hline $\mathrm{Am}^{4+}$ & 6 & & 280 & & & & & & & \\
\hline $\mathrm{se}^{4+}$ & 8 & & 2845 & & & & & & & \\
\hline $\mathrm{P}^{4+}$ & 4 & & 2016 & & & & & & & \\
\hline
\end{tabular}


Table III. Complex Stability Constants for Selected Pentavalent Actinides

\begin{tabular}{|c|c|c|c|c|c|c|c|c|c|c|}
\hline \multirow[b]{2}{*}{ Specien } & \multirow{2}{*}{ U } & \multicolumn{9}{|c|}{ LIrend } \\
\hline & & 엳 & $F$ & $C$ & $\mathrm{NO}_{3}^{-}$ & $\mathrm{H}_{2} \mathrm{PO}_{4}^{-}$ & $\mathrm{CO}_{3}^{2-}$ & $30^{2-}$ & $\mathrm{HPO}^{2-}$ & $\mathrm{pO}_{1}^{\mathrm{J}}$ \\
\hline $\mathrm{Am} \mathrm{O}^{\circ}$ & 1 & 48 & 0.82 & -151 & -1.22 & 1.04 & 5.07 & 153 & 3.14 & 6.78 \\
\hline $\mathrm{NPO}^{+}$ & 1 & 4.11 & 0.22 & -1.51 & $-1,42$ & 1.04 & 5.07 & 1.53 & 3.34 & 5.78 \\
\hline $\mathrm{mi}^{\circ}$ & 1 & 4.4 & 0.5 & $-|S|$ & $-1,42$ & 1.04 & 5,07 & 193 & 281 & 6.78 \\
\hline $\mathrm{AnO}^{\circ}$ & 2 & & & -3.00 & -2.12 & & 1.62 & & & \\
\hline $\mathrm{N}: \mathrm{O}^{\circ}$ & 2 & & & -3.00 & -2.12 & & 6.62 & & & \\
\hline $\mathrm{NO}^{+}$ & 2 & & & -3.00 & -212 & & 6.02 & & & \\
\hline $\mathrm{AmO}^{+}$ & 3 & & & & & & 736 & & & \\
\hline $\mathrm{NeO}$ & 1 & & & & & & 1.55 & & & \\
\hline $\mathrm{MO}_{2}^{+}$ & 3 & & & & & & 7.36 & & & \\
\hline
\end{tabular}

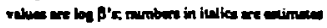

Table IVa. Complex Stability Constants for Selected Hexavalent Artinides

\begin{tabular}{|c|c|c|c|c|c|c|c|c|c|c|}
\hline \multirow[b]{2}{*}{ Specien } & \multirow{2}{*}{ Lignds } & \multicolumn{9}{|c|}{ Wlund } \\
\hline & & Orr & $F$ & $\mathrm{Cr}^{-}$ & $\mathrm{NO}_{7}$ & $\mathrm{H}_{2} \mathrm{PO}_{1}^{-}$ & $\mathrm{CO}^{2-}$ & $\mathrm{so}_{1}^{2-}$ & $\mathrm{HPO}_{4}^{2}$ & $\mathrm{PO}^{3}$ \\
\hline $\operatorname{Am} 0^{2-1}$ & 1 & 8.78 & $\$ .05$ & 0.15 & 0.24 & 4.49 & 9.66 & 3.06 & 854 & \\
\hline $\mathrm{NpO}_{3}$ & 1 & 8.90 & 5.10 & 0.20 & -0.30 & 243 & 9.68 & 200 & 8.5 & \\
\hline $\mathrm{PuO}_{3}$ & 1 & 8.62 & 4.68 & 0.50 & 0.24 & 1.49 & 9.31 & 3.38 & 854 & \\
\hline $\mathrm{AmO}^{2+}$ & 2 & 15.97 & 854 & -1.12 & 0.01 & 755 & 16.96 & 3.99 & & \\
\hline $\mathrm{NPO}_{3}^{20}$ & 2 & 15.97 & 7.56 & 0.10 & 0.01 & 755 & 16.96 & 4.64 & & \\
\hline $\mathrm{PuO}_{2}$ & 2 & 15.54 & 8.37 & -0.18 & 0.01 & 755 & 18.10 & 3.99 & & \\
\hline $\mathrm{AmO}^{2+}$ & 3 & 21.72 & 10.78 & & & & $215 d$ & & & \\
\hline $\mathrm{NPO}^{2+}$ & 3 & 21.72 & 9.57 & & & & 21.58 & & & \\
\hline $\mathrm{HO}_{3}$ & 3 & $21 . n$ & $10.7 \mathrm{~s}$ & & & & 18.35 & & & \\
\hline Amó & 4 & 22.93 & 1154 & & & & & & & \\
\hline $\mathrm{N}+\mathrm{O}_{3}^{2+}$ & 4 & 22.95 & 11.54 & & & & & & & \\
\hline $\mathrm{PuO}_{4}^{2-}$ & 4 & 22.93 & 1154 & & & & & & & \\
\hline
\end{tabular}

nues are bi B's number in inlice an minere

Table IVt. Complex Stability Constants for Selected Itexavalent Actinides

\begin{tabular}{|c|c|c|c|c|}
\hline \multirow[b]{2}{*}{ Species } & \multirow{2}{*}{$\begin{array}{c}\text { A } \\
\text { Radienuclide }\end{array}$} & \multirow{2}{*}{ Lirends } & \multicolumn{2}{|c|}{ الd Land } \\
\hline & & & olr & $\mathrm{CO}^{2}$ \\
\hline $\mathrm{Ama}^{2+}$ & 2 & 1 & 11.18 & \\
\hline $\mathrm{NpO}^{2+}$ & 2 & 1 & II.18 & \\
\hline $\mathrm{PuO}^{\circ}$ & 2 & 1 & 11.18 & \\
\hline $\mathrm{AmO}$ & 2 & 2 & 22.12 & \\
\hline $\mathrm{NpO}_{3}^{2}$ & 2 & 2 & 22.32 & \\
\hline $\mathbf{P O}$ & 2 & 2 & 20.4 & \\
\hline $\mathrm{AmO}$ & 3 & 4 & 403 & \\
\hline $\mathrm{N}: \mathrm{O}^{\circ}$ & 3 & 4 & 44.03 & \\
\hline $\mathrm{PuO}_{3}^{2}$ & 3 & 4 & $0,0\}$ & \\
\hline$A \pi O^{2}$ & 3 & 5 & 5415 & \\
\hline $\mathrm{NpO}^{2}$ & 3 & 5 & S4.35 & \\
\hline PuO & 3 & 3 & 49.75 & \\
\hline $\mathrm{AmO}$ & 3 & 6 & & 53.75 \\
\hline $\mathrm{NgO}_{3}$ & 3 & 6 & & 53.75 \\
\hline Puo & 3 & 6 & & 53.75 \\
\hline$A m O^{2}$ & 3 & 7 & 6688 & \\
\hline $\mathrm{NpO}_{3}^{\mathrm{tH}}$ & 3 & 7 & 66.4 & \\
\hline Pua & 3 & 7 & 6680 & \\
\hline$A m O^{2}$ & 4 & 7 & 75,48 & \\
\hline $\mathrm{NpO}_{3}$ & 4 & 7 & 75.94 & \\
\hline $\mathrm{no}^{2+}$ & 4 & 7 & 75.90 & \\
\hline
\end{tabular}

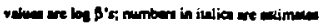


COMPARISON OF EXPERIMENTAL AND MODELING RESULTS

\section{Neotunium}

Results of the neptunium solubility experiments are shown in Figure 1. The steadystate solids in each experiment were sodium neptunium carbonate hydrates with different water content. The solid formed at $90^{\circ} \mathrm{C}$ and $\mathrm{pH} 7$ was a mixture of sodium neptunium carbonate hydrate and neptunium pentoxide. The solubility decreased at each temperanure with increasing $\mathrm{pH}$; this is due to the increasing concentration of $\mathrm{CO}_{3}^{2}$ with increasing $\mathrm{pH}$, resulting in lower solubilities through the formation of more insoluble sodium neptunium carbonate hydrates. The comparison of the experimental results with the modeling calculations is shown in Figure 2. The experimental solubilities are significantly higher than the calculated ones. This is not surprising because the model predicted $\mathrm{NpO}_{2}$ (c) instead of $\mathrm{NaNPO}_{2} \mathrm{CO}_{3} \cdot 2.5 \mathrm{H}_{2} \mathrm{O}$ as the solubility-controlling solid. The EQ $3 / 6$ thermodynamic data base does not contain solubility data for $\mathrm{NaNpO}_{2} \mathrm{CO}_{3} \cdot 2.5 \mathrm{H}_{2} \mathrm{O}$.

Measured and calculated solution species are compared in Figures 3, 4, and 5. Uncomplexed $\mathrm{NpO}_{2}{ }^{+}$and the $\mathrm{NpO}_{2} \mathrm{CO}_{3}$-complex were correctly predicted as being the major species. Good agreement was obtained for $\mathrm{pH} 6$ and 8.5. At pH 8.5, small amounts of higher neptunyl(V) carbonate complexes and of $\mathrm{NpO}_{2} \mathrm{OH}$ were calculated by the model. At $\mathrm{pH} 7$, the simulation overestimated the amount of $\mathrm{NpO}_{2}^{+}$and underestimated the $\mathrm{NpO}_{2} \mathrm{CO}_{3}^{-}$ concentration.

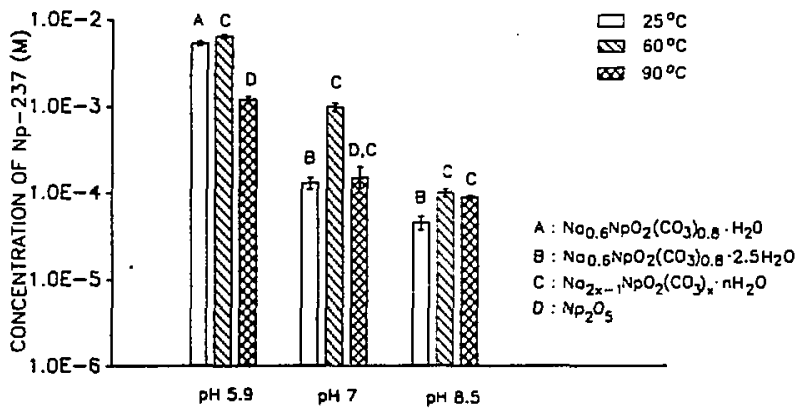

Figure 1. Results of Neptunium(V) Solubility Experiments in J-13 Groundwater as a Function of $\mathrm{pH}$ and Temperature.

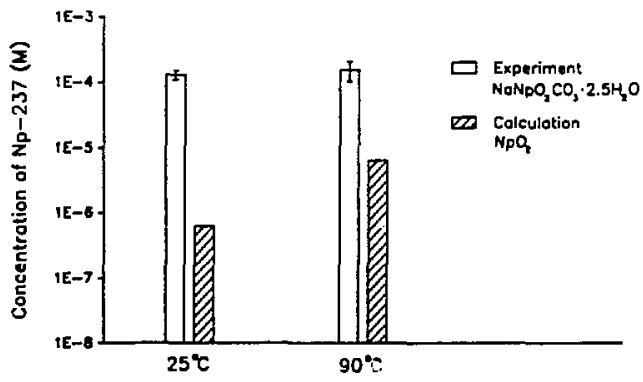

Figure 2. Neptunium Solubility in J-13 Groundwater at pH 7; Comparison Between Experimental Results and Modeling Calculations. 


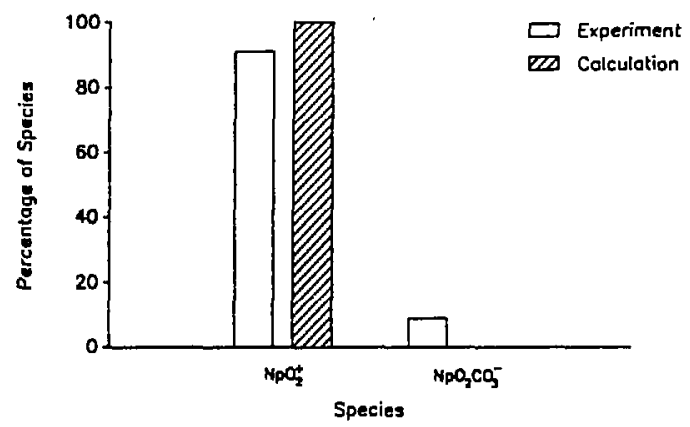

Figure 3. Neptunium Speciation in J-13 Groundwater at $\mathrm{pH} 6$ and $25^{\circ} \mathrm{C}$; Comparison Between Experimental Results and Modeling Calculations.

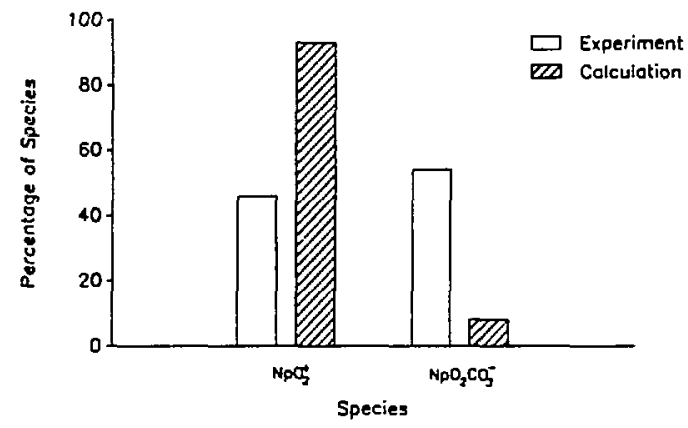

Figure 4. Neptunium Speciation in J-13 Groundwater at $\mathrm{pH} 7$ and $25^{\circ} \mathrm{C}$; Comparison Between Experimental Results and Modeling Calculations.

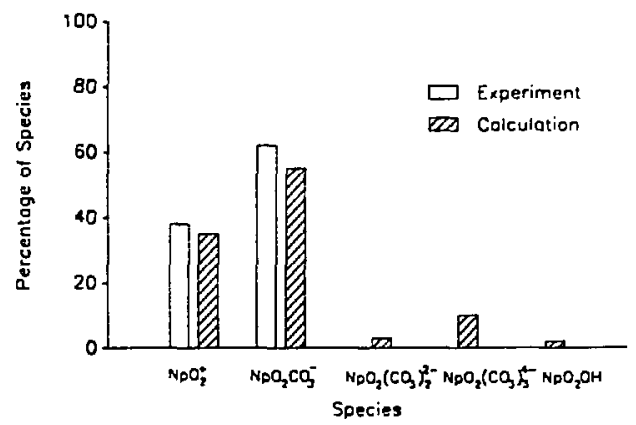

Figure 5. Neptunium Speciation in J-13 Groundwater at pH 8.5 and $25^{\circ} \mathrm{C}$; Comparison Between Experimental Results and Modeling Calculations. 
Plutonium

Results of the tetravalent plutonium solubility study are shown in Figure 6 . The solubility-controlling solids were mixtures containing mainly polymeric plutonium(IV) and smaller portions of plutonium carbonates. This explains the drastic decrease in plutonium solubility with increasing temperature. The plutonium(IV) polymer peptizes with increasing temperature and becomes more stable; over extremely long times it may possibly convert to $\mathrm{PuO}_{2}$. The comparisons are shown in Figures 7 and 8. Very large discrepancies exist between the experiment and the simulation. The simulation results improved when amorphous hydrous plutonium dioxide $\left(\mathrm{PuO}_{2} \cdot \mathrm{H}_{2} \mathrm{O}\right.$ or $\left.\mathrm{Pu}(\mathrm{OH})_{4}\right)$ was assumed as the solid phase instead of crystalline plutonium dioxide. Hydrous plutonium dioxide or plutonium(IV) polymer, however, is thermodynamically ill-defined, and the solubility product constant used in the data base may not be applicable to other polymeric plutonium(IV) precipitates. Such precipitates may differ in their amorphous composition, which may result in higher or lower solubilities.

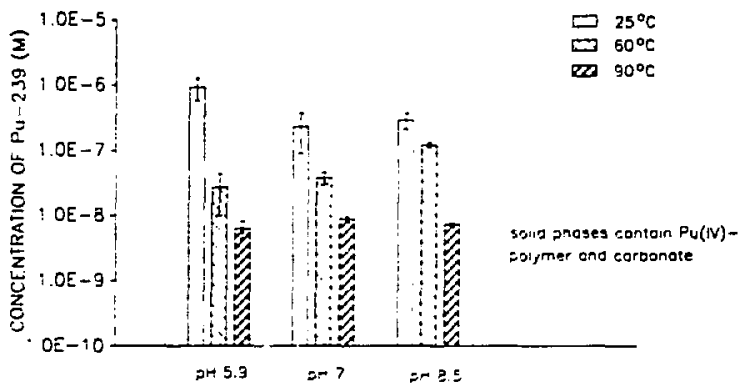

Figure 6. Results of Plutonium(IV) Solubility Experiments in J-13 Groundwater as a Function of $\mathrm{pH}$ and Temperature.

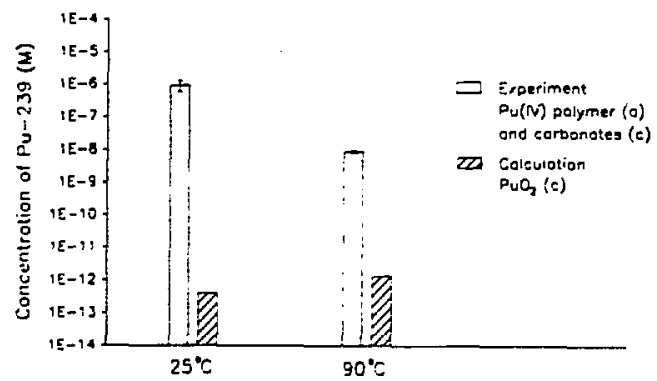

Figure 7. Plutonium Solubility in $\mathrm{J}-13$ Groundwater at $\mathrm{pH} 7$; Comparison Between Experimental Results and Modeling Calculations.

Measured plutonium oxidation-state distributions of the steady-state solutions and the comparison with modeling calculations are shown in Figures 9, 10, and 11. Due to the low plutonium concentrations, we could not apply direct speciation techniques, such as laserinduced photoacoustic spectroscopy. We used an indirect method of combined extraction and coprecipitation techniques instead, which can identify only the oxidation state and not the individual solution species [7]. Both the experimental measurements and the speciation simulations identified plutonium(V) and plutonium(VI) as the major oxidation states; the plutonium was added initially to the groundwater as Pu+4. This is mainly due to a revised, more reasonable value of $\log B=12.3$. Experiments by Silva and Nitsche [11] identified this 


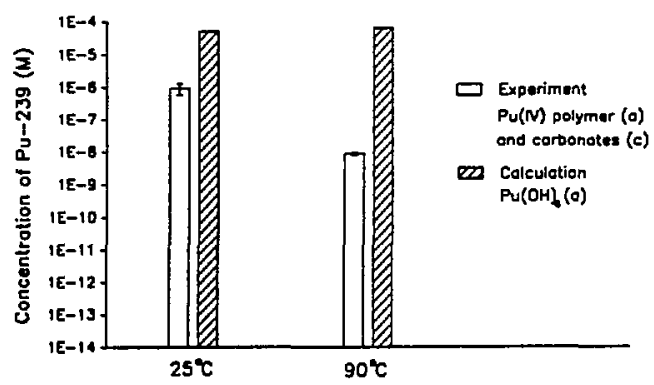

Figure 8. Plutonium Solubility in $\mathrm{J}-13$ Groundwater at $\mathrm{pH} \mathrm{7;} \mathrm{Comparison} \mathrm{Between}$ Experimental Results and Modeling Calculations.

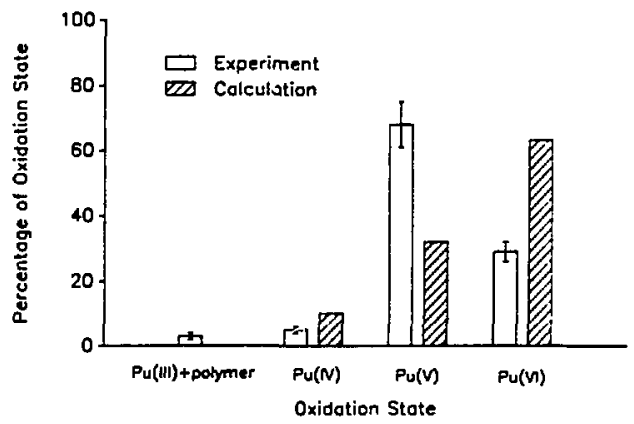

Figure 9. Plutonium Oxidation State Distributions in J-13 Groundwater at pH 6 and $25^{\circ} \mathrm{C}$; Comparison Between Experimental Results and Modeling Calculations.

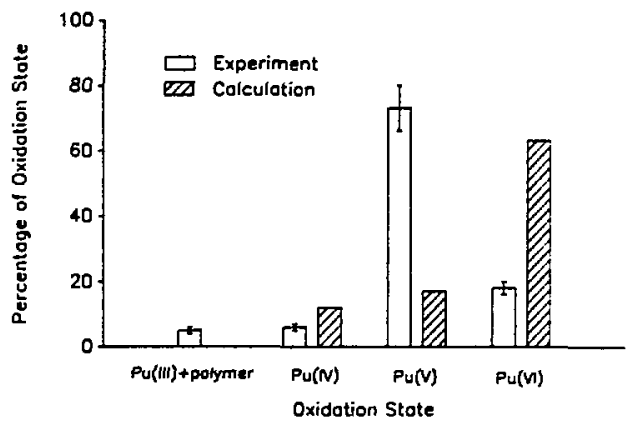

Figure 10. Plutonium Oxidation State Distributions in $\mathrm{J}-13$ Groundwater at $\mathrm{pH} 7$ and $25^{\circ} \mathrm{C}$; Comparison Between Experimental Results and Modeling Calculations. 


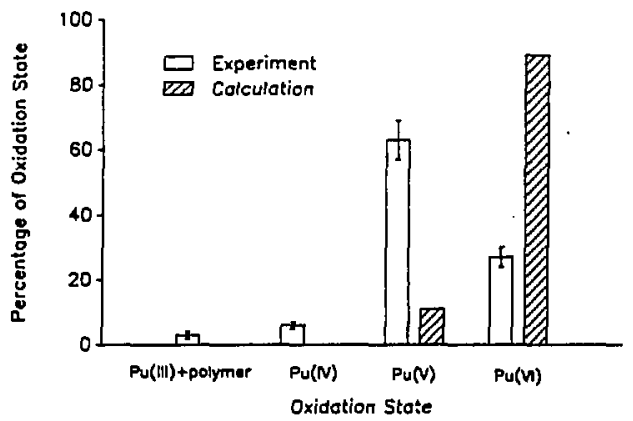

Figure 11. Plutonium Oxidation State Distributions in J-13 Groundwater at $\mathrm{pH} 8.5$ and $25^{\circ} \mathrm{C}$; Comparison Between Experimental Results and Modeling Calculations.

value as an upper limit; the actual number is as yet undetermined and may be substantially smaller. Values ranging between 17.0 and 47.0 for $\log B$ can be found in the literature $[12$, 13]. Using such extremely high and unrealistic stability constants would result in the tetravalent plutonium carbonate complex being the predominant solution species at steady state; this would completely disagree with the experimental results. Large differences exist, however, between experiment and simulation in the individual oxidation-state distribution. Although the measurements indicated relatively large amounts of plutonium(V) and smaller quantities of plutonium(VI), the simulation predicted nearly reversed distributions for all three $\mathrm{pH}$ values-large quantities of plutonium(VI) and smaller amounts of plutonium( $\mathrm{V}$ ). The plutonium species distributions, as calculated by Miller and Silva [10], are shown in Table V.

Table V. Speciation Calculations for Plutonium in J-13 Groundwater

\begin{tabular}{|c|c|c|c|}
\hline Specics & $\mathrm{pH} 6$ & $\begin{array}{c}\text { Distribution (\%) } \\
\mathrm{pH} 7\end{array}$ & $\mathrm{pH} 8.5$ \\
\hline $\mathrm{Pu}\left(\mathrm{HPO}_{4}\right)_{4}^{4-}$ & 10 & 12 & - \\
\hline $\mathrm{PuO}_{2}^{+}$ & 32 & 17 & 2 \\
\hline $\mathrm{PuO}_{2} \mathrm{CO}_{3}^{-}$ & - & - & 9 \\
\hline $\mathrm{PuO}_{2} \mathrm{CO}_{3}^{-}$ & 34 & 53 & 6 \\
\hline $\mathrm{PuO}_{2}\left(\mathrm{CO}_{2}\right)_{3}^{2-}$ & - & 3 & 8 \\
\hline $\mathrm{PuO}_{2}\left(\mathrm{CO}_{3}\right)_{3}^{4-}$ & - & & 7 \\
\hline$\left(\mathrm{PuO}_{2}\right)_{3}\left(\mathrm{CO}_{3}\right)_{6}^{--}$ & - & 2 & 15 \\
\hline $\mathrm{PuO}_{2} \mathrm{OH}^{+}$ & 3 & - & - \\
\hline $\mathrm{PuO}_{2}(\mathrm{OH})_{3}^{-}$ & - & - & 8 \\
\hline$\left(\mathrm{PuO}_{2}\right)_{3} \mathrm{OOH}_{3}$ & - & - & 45 \\
\hline $\mathrm{PuO}_{2} \mathrm{~F}^{+}$ & 4 & - & - \\
\hline $\mathrm{PuO}_{2} \mathrm{~F}_{2}$ & 2 & - & - \\
\hline $\mathrm{PuO}_{2} \mathrm{HPO}_{4}$ & 15 & 6 & - \\
\hline Others & - & 7 & - \\
\hline
\end{tabular}


The main species at pH 8.5 are plutonium(V) and plutonium(VI) carbonate complexes and plutonium(IV) hydrolysis products. At $\mathrm{pH} 7, \mathrm{PuO}_{2} \mathrm{CO}_{3}$ and uncomplexed $\mathrm{PuO}_{2}{ }^{+}$are present together with plutonium(IV) and plutonium(VI) hydrogen phosphate complexes. Phosphate complexation in $\mathrm{J}-13$ groundwater may be somewhat surprising, because many analyses of $\mathrm{J}$ 13 groundwater do not list phosphate, although it was found to be present at a level of 0.12 ppm [14]. At pH 6, the major species are plutonium(IV) and plutonium(VI) hydrogen phosphate, plutonium (V) carbonate, and uncomplexed $\mathrm{PuO}_{2}^{+}$; minor species are plutonium(VI) fluorides and $\mathrm{PuO}_{2} \mathrm{OH}^{+}$.

\section{Americium}

Results of the americium solubility experiments are shown in Figure 12. No clear trend of the solubility was found with increasing temperature and increasing $\mathrm{pH}$. Much higher solubilities were found for $60^{\circ} \mathrm{C}$ compared with $25^{\circ} \mathrm{C}$ and $90^{\circ} \mathrm{C}$. All solids were AmOHCO, with orthorhombic structure for all temperatures at $\mathrm{pH} 7$ and 8.5 and for $60^{\circ} \mathrm{C}$ at $\mathrm{pH} 6$ and with hexagonal structure for $25^{\circ} \mathrm{C}$ and $90^{\circ} \mathrm{C}$ at $\mathrm{pH} 6$. Orthorhombic $\mathrm{AmOHCO}$, appears to have a much higher solubility at $\mathrm{pH} 6$ and $60^{\circ} \mathrm{C}$ than the hexagonal form at the same $\mathrm{pH}$ and $25^{\circ} \mathrm{C}$ or $90^{\circ} \mathrm{C}$.

Comparisons between the experimental results and the modeling calculations are shown in Figure 13. Reasonable agreement was achieved at $25^{\circ} \mathrm{C}$, where the simulation identified $\mathrm{AmOHCO}$, as the solubility-controlling solid. The modeling calculation predicted the $90^{\circ} \mathrm{C}$ solid incorrectly as $\mathrm{Am}(\mathrm{OH})_{3}$, resulting in too high a solubility.

Because of the low americium concentration, we could not determine the solution speciation, but we found that the soluble americium(III) did not change its oxidation state during the experiment. Simulation calculations indicated that at $\mathrm{pH} \mathrm{6,} \mathrm{Am}^{3+}, \mathrm{AmCO}_{3}{ }^{+}$, $\mathrm{AmOH}^{2+}$, and $\mathrm{AmSO}_{4}^{+}$are major species and that $\mathrm{AmF}^{2+}$ and $\mathrm{AmF}_{2}^{+}$are minor species. The $\mathrm{pH} 7$ calculation showed that $\mathrm{AmCO}_{3}{ }^{+}$and, to a lesser extent, $\mathrm{AmOH}^{2+}$ and $\mathrm{Anm}^{3+}$ are the major species. At pH 8.5, $\mathrm{AmCO}_{3}{ }^{+}$and $\mathrm{Am}\left(\mathrm{CO}_{3}\right)_{2}{ }^{-}$were major and hydrolytic americium species minor solution components.

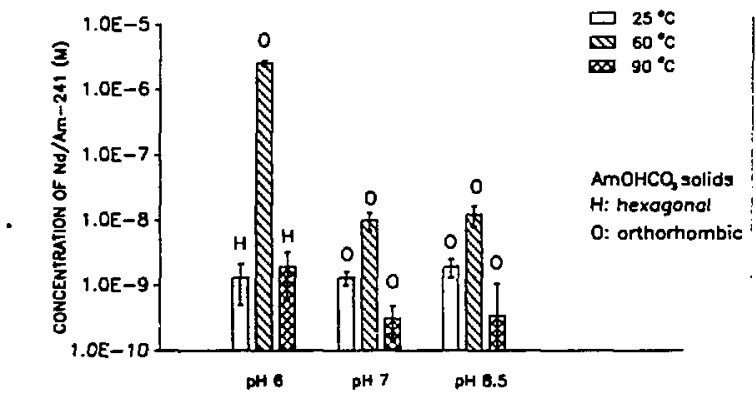

Figure 12. Results of Americium(III) Soubility Experiments in J-13 Groundwater as a Function of $\mathrm{pH}$ and Temperature. 


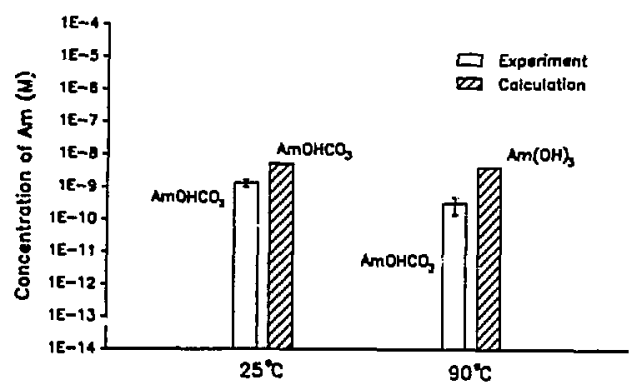

Figure 13. Annericium Solubility in $\mathrm{J} \cdot 13$ Groundwater at $\mathrm{pH} 7$; Comparison Between Experimental Results and Modeling Calculations.

\section{CONCLUSIONS AND RECOMMENDATIONS}

The comparison of results from experimental solubility measurements with modeling calculations indicates that there is great need to improve the presently existing thermodynamic data base. This study, though limited in scope, shows that data for steady-state solids of some radionuclides are missing in the data base (e.g., $\mathrm{NaNpO}_{2} \mathrm{CO}_{3} \cdot 2.5 \mathrm{H}_{2} \mathrm{O}$, hexagonal $\mathrm{AmOHCO}_{3}$, a range of amorphous plutonium(IV) hydrous oxide solubility products instead of one single value). Very limited data are available for higher temperatures. Speciation calculations indicate that compiex stability constants for neptunium and americium are sufficiently well represented in the data base. But application of comprehensive sensitivity analyses for these systems are indicated, because relatively small changes in the stability constants may improve agreement with the experimental findings.

Generally, solubility and complexation studies at higher temperatures, up to $150^{\circ} \mathrm{C}$, are recommended in order to improve predictive modeling capabilities for scenarios that represent temperatures in the near field.

It is also of great interest to know how alpha self-irradiation affects the solubility of secondary solids. For example, is the solubility of short-lived ${ }^{20 \mathrm{Pu}}$ significantly higher than that of ${ }^{212} \mathrm{Pu}$, with a 4483 times longer half-life?

Furthermore, model and data base validation should be extended through intermediatescale experiments and field tests. Kinetic limitations and heterogeneity of the geomedia should be incorporated in chemical/transport models. Solubility studies and subsequent comparison with results from modeling calculation should be extended to other important nuclear waste radionuclides, such as nickel, zirconium, cadmium, radium, and thorium.

In summary, we have shown in this paper that experimental solubility and speciation studies are useful and very important in understanding radionuclide transport through the geosphere.

\section{ACKNOWLEDGMENTS}

I would like to thank my co-workers R. C. Gatti, R. J. Deinhammer, S. C. Lee, A. Müller, T. Prussin, S. A. Carpenter, and E. M. Standifer for their skillful assistance with the experimental work. I am indebted to C. Miller and R. J. Silva nf Lawrence Livermore National Laboratory for fumishing their speciation calculations and data base.

This work was supported by the Yucca Mountain Site Characterization Project Office as part of the U.S. Civilian Radioactive Waste Management Project through the Los Alamos National Laboratory. The Yucca Mountain Project is managed by the U.S. Department of Energy, Yucca Mountain Project. This work was performed at the Lawrence Berkeley Laboratory, which is operated by the University of California for the U.S. Department of Energy under Contract DE-AC03-76SF00098. 


\section{REFERENCES}

1. K.W. Thomas, Summary of Sorption Measurements Performed with Yucca Mountain. Nevada. Tuff Samples and Warer from Well J-13, Report LA-10960MS (Los Alamos National Laboratory, New Mexico, 1985).

2. R.E. Meyer, W.D. Amold, G.D. O'Kelley, F.I. Case, J.F. Land, Progress in Evaluation of.Radionuclide Geochemical Information Developed by DOE High-Level Nuclear Waste Repository Site Projects. Report NUREG/CR-47081//ORNL/TM-10147/N3 (Oak Ridge National Laboratory, Oak Ridge, Tennessee, 1989).

3. D.E. Yates, S. Levine, T.W. Healy, J. Chem. Soc. Faraday Trans. I 170, 1807-1818 (1974).

4. J.A. Davies and J.O. Leckie, J. Colloid Interface Sci. 67, 90-107 (1978); 74 32-43 (1980).

5. J. A. Davies, J. O. Leckie, ibid., 63 (3), 480-499 (1978).

6. H. Nitsche, Solubility Studies of Transuranium Elements for Nuclear Waste Disposal: Principles and Overview, Radiochim. Acta in press (1991).

7. H. Nitsche, S.C. Lee, R.C. Gatti, J. Radioanal. Nucl. Chem., 124 (1), 171-185 (1988).

8. C.N. Wilson and C. J. Bruton, Studies on Spent Fuel Dissolution Behavior under Yucca Mountain Repository Conditions, Report PNL-SA-16832 (or UCRL-10023) (Pacific Northwest Laboratory, Richland, Washington, 1989).

9. T.J. Wolery, EO3NR. A Computer Program for Geochemical Aqueous Speciations Solubility Calculations: User's Guide and Documentation, Report UCRL-53414 (Lawre: ¿ Livermore National Laboratory, Livermore, California, 1987).

10. C. Miller and R.J. Silva (private communication), publication in preparation.

11. R. J. Silva and $\mathrm{I}$. Nitsche, Carbonate Complexation of Pu(TV) in Aqueous Solution, presented at the 189 th American $\mathrm{Cr}$ mical Society National Meeting, Miami Beach, Florida, 1985 (unpublished).

12. J.I. Kim, G. Buckau, K. Büppelmann, R. Klenze, Ch. Lierse, S. Stadler, Chemisches Verhalten von $\mathrm{Np}$. $\mathrm{Pu}$ und Am unter natïrlichen aquatischen Bedingungen Report RCM 00988 (Institut für Radiochemie, Technische Universität München, Garching, Germany, 1988) p. 41.

13. A.I. Moskvin and A.D. Gelman, Zhumal Neorganicheskoi Khimii 3 (4), 962 (1958) [J. of Inorg. Chem. USSR 3 (4), 198 (1958)].

14. W.R. Daniels et al., in Summary Report on the Geochemistry of Yucca Mountain and Environs, Report LA-10188-MS (Los Alamos National Laboratory, Los Alamos, New Mexico, 1982) p. 21. 
APPENDDX

The data used to write this report are recorded in the following YMP Laboratory Record Books:

TWS-LBL-05-88-01, pp. 3-299;

TWS-LBL-05-88-02, pp. 3-251;

TWS-LBL-01-89-01, pp. 99-293;

TWS-LBL-01-89-02, pp. 3-251;

TWS-LBL-07-89-01, pp. 5-75;

TWS-LBL-02-90-03, pp. 31-75;

TWS-LBL-02-90-04, pp. 63-188. 